\title{
A systematic review of Hepatitis C virus treatment uptake among people who inject drugs in the European Region
}

\author{
Jeffrey $V$ Lazarus $^{1 *}$, Ida Sperle ${ }^{1}$, Mojca Maticic ${ }^{2}$, Lucas Wiessing ${ }^{3}$
}

\begin{abstract}
Background: Fifteen million adults in the World Health Organization European Region are estimated to have active hepatitis $C$ infection. Intravenous drug use is a major hepatitis $C$ transmission route in this region, and people who inject drugs (PWID) constitute a high-risk and high-prevalence population. A systematic review was conducted to assess levels of hepatitis $C$ treatment uptake among PWID in Europe.

Methods: Searches in MEDLINE and EMBASE were carried out for articles in any language published between 1 January 2000 and 31 December 2012. Articles were included in the review if they presented original research findings about hepatitis $C$ treatment uptake levels among people who reported injecting drugs currently or formerly, as well as those who reported using drugs currently or formerly (mode of consumption not specified). Treatment uptake data were extracted if uptake was measurable in relation to the number of patients who either:

(a) tested HCV antibody-positive; (b) tested positive for HCV-RNA; or (c) tested positive for HCV-RNA and met additional treatment criteria.

Results: Twenty-five articles from 12 countries were included in the review. Among groups of drug-using study participants who were hepatitis C antibody-positive, the median treatment uptake level was $17 \%$, and among those who were hepatitis C RNA-positive, the median was 30\%. In the 11 studies reporting specifically on treatment uptake among current and former injecting drug users, hepatitis C RNA-positive study populations had a median treatment uptake level of 32\%. Only one study reported on treatment uptake for current drug users.

Conclusions: This systematic review indicates that hepatitis $C$ treatment uptake is relatively low among drug users in several European countries, and also points to considerable knowledge gaps regarding treatment uptake levels in this population. There was large variability in treatment uptake levels, suggesting that there may be major differences between and within countries in relation to treatment availability, drug-using populations in need of treatment, and the existence of integrated health care services targeting drug users. Stronger national hepatitis $C$ treatment policies are needed, along with efforts to increase knowledge and reduce misconceptions among physicians regarding the feasibility and importance of treating drug users who have hepatitis $C$.
\end{abstract}

\section{Introduction}

An estimated 185 million people worldwide have acquired the hepatitis $\mathrm{C}$ virus (HCV) [1], many of them without being aware of their infection. Chronic disease can be expected to occur in $55 \%$ to $85 \%$ of untreated cases, and potential long-term outcomes for chronically infected people include liver cirrhosis, liver failure and

\footnotetext{
${ }^{1} \mathrm{CHIP}$, Centre for Health and Infectious Disease Research and WHO Collaborating Centre on HIV and Viral Hepatitis, Rigshospitalet, University of Copenhagen, Copenhagen, Denmark

Full list of author information is available at the end of the article
}

hepatocellular carcinoma [2]. A 2006 assessment of the global burden of disease from hepatitis $B$ and hepatitis $C$ put annual HCV-related mortality at 366,000 [3], while more recent research yielded an estimate of 499,000 deaths due to $\mathrm{HCV}$ in 2010 [4].

In the World Health Organization (WHO) European Region, 15 million adults are estimated to have active HCV infection as defined by the presence of HCV-RNA. This translates into a regional adult prevalence rate of $2.0 \%$ [5]. While the limitations of the available data invite some uncertainty about the magnitude of the 
$\mathrm{HCV}$ epidemic in the region overall, numerous studies provide evidence of high $\mathrm{HCV}$ antibody levels (indicating either current or previous infection) in specific countries and subnational regions. For example, a 2013 review article identified reports of $\mathrm{HCV}$ antibody prevalence levels in the general population ranging from $0.1 \%$ to $22 \%$ at the national and subnational level in 13 European countries. The article observed that prevalence was lower in northwestern European countries and higher in the countries of the south and southeast [6].

Injecting drug use is a major driver of the HCV epidemic in Europe. According to the 2013 European Drug Report: Trends and Developments, injecting drug use accounted for $58 \%$ of all HCV diagnoses across 18 European countries for which 2010/2011 data were available [7]. An analysis of HCV-RNA prevalence data from the WHO European Region concluded that two million of the region's 15 million adults with HCV-RNA are people who inject drugs (PWID) [5]. While wide-ranging HCV antibody prevalence levels have been found across different PWID cohorts, overall prevalence in this population appears to be much higher than in the general population. According to a 2013 systematic review, HCV antibody prevalence among PWID in 29 European countries ranged from 5\% to 90\% [6]. The 2013 European Drug Report noted that in eight of 12 countries with HCV antibody data from national samples of PWID, prevalence exceeded 40\% [7].

Effective and safe HCV treatment can be used in the majority of infected patients and would greatly reduce the associated morbidity and mortality. Several studies have shown that HCV treatment outcomes in PWID are comparable to those in patients with no history of drug use $[8,9]$. Additionally, treatment also helps to prevent transmission by eliminating the potential source of infection [10]. Nevertheless, current treatment uptake overall is low, and treatment rates appear to be lowest among the most affected at-risk group: PWID [11]. Barriers to HCV treatment are most likely to be present on different levels including the patient, provider and system levels [11]. These barriers may include a lack of knowledge, a lack of financial resources and a fear of side-effects among patients, as well as concerns of adherence and the risk of re-infection at the provider level [11]. Another barrier is the setting itself, which needs to be suitable for this group and able to adequately handle different needs in this vulnerable population [12] as well as address associated stigma [13].

The purpose of this article is to systematically review the evidence on hepatitis $C$ virus treatment uptake among PWID in the WHO European Region.

\section{Methods}

We performed a systematic review of literature on $\mathrm{HCV}$ treatment uptake among PWID in the WHO European Region (Figure 1). Searches were carried out in MEDLINE and EMBASE for articles in any language published between 1 January 2000 and 31 December 2012. A sensitive search string (available upon request) was developed with keywords covering hepatitis $C$ virus, substance abuse, geographic scope and access to treatment. Additional articles, including grey literature articles, were located through e-mail consultations with a network of experts representing 27 European Union countries. The protocol was made consistent with the PRISMA criteria as described elsewhere $[14,15]$. This study draws upon the protocol of a similar systematic review on treatment uptake among PWID [15], but important differences in inclusion and exclusion criteria and reporting of the results explains the differences in the findings.

Two researchers independently screened search results for relevance on the basis of titles and abstracts, then compared their findings. When there was uncertainty about the relevance of an item, it was retained for further consideration. Next, two researchers independently evaluated all potentially relevant articles on the basis of the full article text using predetermined inclusion and exclusion criteria (Box 1). Additional articles were identified and screened by examining the reference lists of articles found to be eligible for inclusion. The final set of articles underwent data extraction. Native speakers provided assistance with screening and data extraction for nonEnglish articles, and online translation services (Google Translate and BabelFish) were utilised as well.

\section{Box 1. Inclusion and exclusion criteria for articles}

\section{Inclusion criteria}

- Original research findings about treatment uptake levels in HCV patient cohorts (not articles reporting on modelling findings or systematic reviews).

- Study participants who reported injecting drugs currently or formerly as well as those who reported using drugs currently or formerly (mode of consumption not specified).

- Treatment uptake level measurable in relation to the number of patients who either: (a) tested HCV antibody-positive; (b) tested positive for HCV-RNA; or (c) tested positive for HCV-RNA and met additional treatment criteria.

- Data collected after 1990.

- Unselected study population.

\section{Exclusion criteria}

- Study cohort comprised solely of people who reported non-injecting drug use.

- Study findings based on modelling rather than actual patient data.

- Use of hepatitis $\mathrm{C}$ treatment determined by patient self-report.

- Confusing, ambiguous or self-contradictory study findings. 


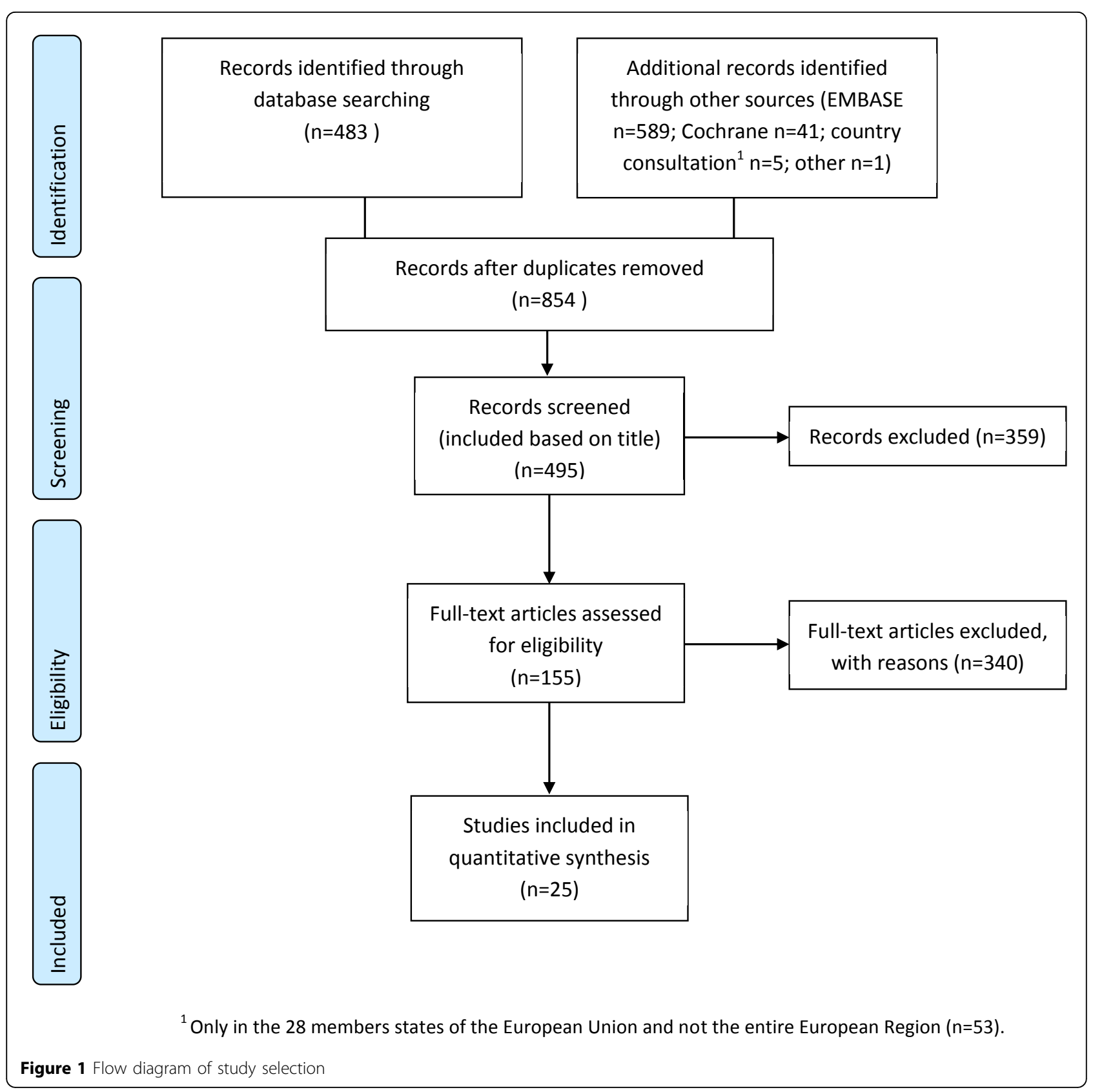

The following primary and secondary outcomes of interest guided data extraction. The primary outcome of interest was the proportion of drug users initiating HCV treatment from among all drug users who were candidates for $\mathrm{HCV}$ treatment; this was regarded as the treatment uptake level. Drug users generally rather than PWID were deemed the population of interest because it was noted that few studies appeared to clearly differentiate among these two populations when reporting treatment uptake levels. We defined candidates for $\mathrm{HCV}$ treatment as those patients who either: (a) tested HCV antibody-positive; (b) tested positive for HCV-RNA; or (c) tested positive for
HCV-RNA and met additional treatment criteria specified in the study protocol. Secondary outcomes of interest were treatment uptake levels for specific types of patient cohorts (e.g., current drug users); levels of sustained viral response (SVR) in treated cohorts; and findings about the age and sex of patients obtaining treatment.

\section{Results}

Studies included in review

Table 1 provides characteristics of the 25 studies included in the review. The studies were carried out in 12 countries. The country with the largest number of studies was 
Table 1 Characteristics of included studies

\begin{tabular}{|c|c|c|c|}
\hline Author, year & Country & Study design & Study population \\
\hline \multicolumn{4}{|c|}{ Study setting: drug treatment clinic } \\
\hline Backmund et al, 2001 & Germany & $\begin{array}{l}\text { Prospective } \\
\text { cohort study }\end{array}$ & $\begin{array}{c}100 \text { drug users who were diagnosed HCV-RNA positive while receiving inpatient } \\
\text { detoxification treatment. HCV treatment exclusion criteria included severe depression } \\
\text { and HIV-positive diagnosis. }\end{array}$ \\
\hline Ebner et al, 2009 & Austria & $\begin{array}{l}\text { Randomised } \\
\text { controlled study }\end{array}$ & $\begin{array}{l}75 \text { HCV-RNA positive drug users diagnosed with opioid dependence and receiving } \\
\text { addiction treatment services. Patients were not eligible for HCV treatment unless they } \\
\text { were undergoing drug maintenance therapy and/or had not used illicit substances for } \\
\qquad \geq 6 \text { months. }\end{array}$ \\
\hline $\begin{array}{l}\text { Grando-Lemaire et al, } \\
2002\end{array}$ & France & $\begin{array}{l}\text { Prospective } \\
\text { cohort study }\end{array}$ & $\begin{array}{l}225 \text { drug users found to be HCV antibody-positive while they were receiving services at } \\
\text { an addiction outpatient unit. Patients were further screened for treatment eligibility via } \\
\text { HCV-RNA testing and liver biopsy. }\end{array}$ \\
\hline Guadagnino et al, 2007 & Italy & $\begin{array}{l}\text { Prospective } \\
\text { cohort study }\end{array}$ & $\begin{array}{l}169 \text { HCV-RNA positive PWID identified at } 11 \text { drug dependency units. These patients } \\
\text { were referred to collaborating infectious diseases clinical centres for evaluation } \\
\text { regarding their suitability for HCV treatment, then the drug dependency units } \\
\text { supervised treatment. }\end{array}$ \\
\hline McCormick et al, 2008 & Ireland & $\begin{array}{l}\text { Prospective } \\
\text { cohort study }\end{array}$ & $\begin{array}{l}13 \text { drug treatment clinic patients who were diagnosed HCV-RNA positive and met } \\
\text { study inclusion criteria. These included being stable on methadone; having a six-month } \\
\text { record of abstinence from intravenous drug use; and having HCV genotype } 2 \text { or } 3 \text {. }\end{array}$ \\
\hline Moussalli et al, 2010 & France & $\begin{array}{l}\text { Cross-sectional } \\
\text { study }\end{array}$ & $\begin{array}{l}337 \text { patients at a drug users' addiction centre: } 113 \text { diagnosed HCV-RNA positive before } \\
\text { an HCV intervention was introduced, and } 224 \text { diagnosed HCV-RNA positive after the } \\
\text { introduction of the intervention, which included an on-site multidisciplinary health care } \\
\text { team. }\end{array}$ \\
\hline Schulte et al, 2010 & Germany & $\begin{array}{l}\text { Prospective } \\
\text { cohort study }\end{array}$ & $\begin{array}{l}301 \mathrm{HCV} \text { antibody-positive people receiving heroin maintenance at five drug treatment } \\
\text { centres. The hepatitis } C \text { treatment study was nested within a heroin maintenance study. }\end{array}$ \\
\hline van der Veen, 2009 & $\begin{array}{l}\text { Netherlands, } \\
\text { the }\end{array}$ & $\begin{array}{l}\text { Retrospective } \\
\text { cohort study }\end{array}$ & Patient files examined for 115 HCV-RNA positive PWID at a drug treatment clinic. \\
\hline Wilkinson et al, 2008 & $\begin{array}{l}\text { United } \\
\text { Kingdom }\end{array}$ & $\begin{array}{l}\text { Retrospective } \\
\text { cohort study }\end{array}$ & $\begin{array}{l}441 \text { HCV-RNA positive drug users identified by offering HCV testing to all patients at a } \\
\text { drug treatment clinic and referringtreatment candidates to a monthly hepatology } \\
\text { outreach clinic within the drug treatment unit. }\end{array}$ \\
\hline Witteck et al, 2011 & Switzerland & $\begin{array}{l}\text { Cross-sectional } \\
\text { study }\end{array}$ & $\begin{array}{l}193 \text { HCV-RNA positive patients identified in opioid substitution programmes in two } \\
\text { Swiss cities. }\end{array}$ \\
\hline \multicolumn{4}{|r|}{ Study setting: hepatitis clinic } \\
\hline Cournot et al, 2004 & France & $\begin{array}{l}\text { Retrospective } \\
\text { cohort study }\end{array}$ & $\begin{array}{l}\text { Data for } 225 \text { HCV antibody-positive PWID including } 41 \text { current PWID analysed as part of } \\
\text { a study of a larger cohort of } 435 \text { people attending inpatient and outpatient clinics at a } \\
\text { hospital hepato-gastroenterology unit. }\end{array}$ \\
\hline Crespo et al, 2001 & Spain & $\begin{array}{l}\text { Prospective } \\
\text { cohort study }\end{array}$ & $\begin{array}{l}416 \text { HCV antibody-positive PWID were among } 1269 \text { people referred for therapeutic } \\
\text { evaluation at a university hospital-based hepatitis clinic. }\end{array}$ \\
\hline Gazdag et al, 2010 & Hungary & $\begin{array}{l}\text { Retrospective } \\
\text { cohort study }\end{array}$ & 83 HCV-RNA positive PWID at a hepatology outpatient clinic. \\
\hline Jowett et al, 2000 & $\begin{array}{c}\text { United } \\
\text { Kingdom }\end{array}$ & $\begin{array}{l}\text { Retrospective } \\
\text { cohort study }\end{array}$ & $\begin{array}{l}253 \mathrm{HCV} \text { antibody-positive patients who attended a regional (referral) liver unit and } \\
\text { who had reported injecting drug use as their main risk factor for HCV. }\end{array}$ \\
\hline Kieran et al, 2011 & Ireland & $\begin{array}{l}\text { Retrospective } \\
\text { cohort study }\end{array}$ & $\begin{array}{l}\text { Subset of } 327 \mathrm{HCV} \text {-RNA positive people reporting injecting drug use as their HCV risk } \\
\text { factor at a clinic for the integrated management of HIV and HCV. }\end{array}$ \\
\hline \multicolumn{4}{|r|}{ Study setting: other/unknown } \\
\hline Broers et al, 2005 & Switzerland & $\begin{array}{l}\text { Prospective } \\
\text { cohort study }\end{array}$ & $\begin{array}{c}22 \text { PWID included in a cohort of } 27 \text { patients offered treatment upon being diagnosed } \\
\text { with acute or subacute hepatitis C. }\end{array}$ \\
\hline Cullen et al, 2007 & Ireland & $\begin{array}{l}\text { Retrospective } \\
\text { cohort study }\end{array}$ & $\begin{array}{l}104 \mathrm{HCV} \text { antibody-positive drug users who were among a cohort of } 196 \text { drug users } \\
\text { prescribed methadone maintenance by general practitioners. }\end{array}$ \\
\hline Defossez et al, 2008 & France & $\begin{array}{l}\text { Cross-sectional } \\
\text { study }\end{array}$ & $\begin{array}{l}\text { HCV antibody-positive people who reported drug use as a presumed mode of infection } \\
\text { in cross-sectional studies of patients newly diagnosed with HCV in 1997, } 2000 \text { and } \\
\text { 2003. (Total numbers of newly diagnosed patients were 69, } 58 \text { and } 96 \text { respectively.) }\end{array}$ \\
\hline Hernandez et al, 2009 & Spain & $\begin{array}{l}\text { Retrospective } \\
\text { cohort study }\end{array}$ & Four HCV-RNA positive PWID in a hospital-based setting. \\
\hline Jack et al, 2009 & $\begin{array}{c}\text { United } \\
\text { Kingdom }\end{array}$ & $\begin{array}{l}\text { Prospective } \\
\text { cohort study }\end{array}$ & $\begin{array}{c}174 \mathrm{HCV} \text { antibody-positive drug users engaged in drug treatment services in a primary } \\
\text { care environment. }\end{array}$ \\
\hline Kristensen et al, 2009 & Norway & $\begin{array}{l}\text { Prospective } \\
\text { cohort study }\end{array}$ & Heroin-dependent patients in medical rehabilitation. \\
\hline
\end{tabular}


Table 1 Characteristics of included studies (Continued)

\begin{tabular}{cccc}
\hline $\begin{array}{c}\text { Lindenburg et al, 2011 } \\
\text { Perez-Alvarez et al, 2012 }\end{array}$ & $\begin{array}{c}\text { Netherlands, } \\
\text { the }\end{array}$ & $\begin{array}{l}\text { Prospective } \\
\text { cohort study }\end{array}$ & 277 HCV antibody-positive drug users referred to a hepatitis C treatment project for \\
drug users.
\end{tabular}

France, with five. Germany, Ireland, Spain and the United Kingdom all had three studies. (One of the three German studies also included study sites in Austria.)

The 25 studies included one randomised controlled study [16], three cross-sectional studies [17-19], 11 retrospective cohort studies [20-30] and 10 prospective cohort studies [31-40]. Ten of the studies took place at drug treatment clinics, five at hepatitis clinics, and ten in other types of settings.

\section{Overall treatment uptake levels and sustained viral response}

Treatment uptake levels were assessed for this review using three different metrics. Some studies reported treatment uptake in terms of more than one metric.

The HCV antibody-positive treatment uptake level reflects the number of study participants who received treatment as a proportion of the number of study participants known to have antibodies for hepatitis $\mathrm{C}$. Ten studies $[19,22,24,26,32,35,36,38-40]$ reported treatment uptake in relation to HCV antibody-positive status (Table 2). Among groups of study participants who were $\mathrm{HCV}$ antibody-positive, treatment uptake ranged from 3\% to $64 \%$ (median: 17\%).
The HCV RNA-positive treatment uptake level reflects the number of study participants who received treatment as a proportion of the number of study participants known to be hepatitis C RNA-positive. Twenty-one studies [16-18,20-34,37,38,40] yielded 22 datasets with information about HCV RNA-positive treatment uptake levels (Table 3). (One study, by Moussalli et al [17], included an observational phase and an intervention phase that enrolled two separate groups of study participants; for the purpose of calculating treatment uptake levels in this review, the information is regarded as though it represents two studies.) Treatment uptake for groups of hepatitis C RNA-positive study participants ranged from $0 \%$ to $61 \%$ (median: $30 \%$ ).

The treatment uptake level for patients who were $\mathrm{HCV}$ RNA-positive and met other criteria reflects the number of study participants who received treatment as a proportion of the number of study participants who both were RNA-positive for hepatitis $\mathrm{C}$ and also met other requirements for treatment, e.g., requirements relating to HCV genotype or to current drug or alcohol intake. Six studies $[19,24,32,38-40]$ reporting on such groups of study participants documented treatment uptake levels ranging from $24 \%$ to $76 \%$ (median, 55\%) (Table 4).

Table 2 Treatment uptake as defined by percentage of hepatitis C antibody-positive study participants who received treatment

\begin{tabular}{|c|c|c|}
\hline Author, year & $\%$ treated (\# treated/\# of treatment candidates) & SVR (\%) (\# with sustained viral response/\# treated) \\
\hline Cournot et al, 2004 & $36 \%(81 / 225)$ & Intent-to-treat: 26\% (26/99) $)^{1}$ \\
\hline Crespo et al, 2001 & $64 \%(268 / 416)$ & NA \\
\hline Cullen et al, 2007 & $3 \%(3 / 104)$ & NA \\
\hline Defossez et al, 2008 & $16 \%(13 / 84)^{2}$ & NA \\
\hline Grando-Lemaire et al, 2002 & $12 \%(27 / 225)$ & $\begin{array}{c}\text { Intent-to-treat: } 19 \%(5 / 27) \\
\text { As-treated: } 33 \%(5 / 15)\end{array}$ \\
\hline Jack et al, 2009 & $17 \%(30 / 174)$ & $\begin{array}{c}\text { Intent-to-treat: 62\% (13/21) } \\
\text { As-treated: 77\% (13/17) }\end{array}$ \\
\hline Jowett et al, 2000 & $20 \%(50 / 253)$ & Intent-to-treat: 36\% (18/50) \\
\hline Kristensen et al, 2009 & $4 \%(6 / 160)$ & NA \\
\hline Lindenburg et al, 2011 & $21 \%(58 / 277)$ & $\begin{array}{c}\text { Intent-to-treat: } 65 \%(37 / 57) \\
\text { As-treated: } 77 \%(37 / 48)\end{array}$ \\
\hline Schulte et al, 2010 & $9 \%(26 / 301)$ & $\begin{array}{l}\text { Intent-to-treat: 69\% (18/26) } \\
\text { As-treated: 86\% (18/21) }\end{array}$ \\
\hline
\end{tabular}

1. Calculated according to the number of treatment outcomes $(\mathrm{N}=99)$ rather than the number of patients $(\mathrm{N}=81)$

2. Study population represents study cohorts from a cross-sectional survey carried out at three time points: $1997(\mathrm{~N}=35), 2000(\mathrm{~N}=19)$ and $2003(\mathrm{~N}=30)$. 
Table 3 Treatment uptake as defined by percentage of hepatitis C RNA-positive study participants who received treatment

\begin{tabular}{|c|c|c|}
\hline Author, year & $\%$ treated (\# treated/\# of treatment candidates) & SVR (\%) (\# with sustained viral response/\# treated) \\
\hline Backmund et al, 2001 & $50 \%(50 / 100)$ & Intent-to-treat: 36\% (18/50) \\
\hline Broers et al, 2005 & $61 \%(11 / 18)$ & $\begin{array}{l}\text { Intent-to-treat: } 56 \%(6 / 11) \\
\text { As-treated: } 100 \%(3 / 3)\end{array}$ \\
\hline Cournot et al, 2004 & $54 \%(81 / 151)$ & Intent-to-treat: $26 \%(26 / 99)^{1}$ \\
\hline Cullen et al, 2007 & $10 \%(3 / 29)$ & NA \\
\hline Ebner et al, 2009 & $23 \%(17 / 75)$ & $\begin{array}{l}\text { Intent-to-treat: 88\% (15/17) } \\
\text { As-treated: 88\% (15/17) }\end{array}$ \\
\hline Gazdag et al, 2010 & $47 \%(39 / 83)$ & NA \\
\hline Grando-Lemaire et al, 2002 & $28 \%(27 / 97)$ & $\begin{array}{l}\text { Intent-to-treat: 19\% (5/27) } \\
\text { As-treated: 33\% (5/15) }\end{array}$ \\
\hline Guadagnino et al, 2007 & $31 \%(53 / 169)$ & $\begin{array}{l}\text { Intent-to-treat: 55\% (29/53) } \\
\text { As-treated: } 85 \%(29 / 34)\end{array}$ \\
\hline Hernandez et al, 2009 & $0 \%(0 / 4)$ & NA \\
\hline Jack et al, 2009 & $25 \%(30 / 118)$ & $\begin{array}{c}\text { Intent-to-treat: 62\% (13/21) } \\
\text { As-treated: 77\% (13/17) }\end{array}$ \\
\hline Jowett et al, 2000 & $29 \%(50 / 172)$ & Intent-to-treat: 36\% (18/50) \\
\hline Kieran et al, 2011 & $21 \%(67 / 327)$ & Intent-to-treat: 43\% (29/67) \\
\hline Lindenburg et al, 2011 & $30 \%(58 / 196)$ & $\begin{array}{l}\text { Intent-to-treat: } 65 \%(37 / 57) \\
\text { As-treated: } 77 \%(37 / 48)\end{array}$ \\
\hline McCormick et al, 2008 & $46 \%(6 / 13)$ & $\begin{array}{l}\text { Intent-to-treat: 83\% (5/6) } \\
\text { As-treated: } 83 \%(5 / 6)\end{array}$ \\
\hline Moussalli et al, $2010^{2}$ & $2 \%(2 / 113)$ & NA \\
\hline Moussalli et al, $2010^{2}$ & $38 \%(85 / 224)$ & Intent-to-treat: 43\% (37/85) \\
\hline Perez-Alvarez et al, 2012 & $56 \%(15 / 27)$ & NA \\
\hline Perut et al, 2009 & $9 \%(12 / 137)$ & NA \\
\hline Reiberger et al, 2011 & $32 \%(201 / 637)$ & NA \\
\hline van der Veen, 2009 & $48 \%(35 / 73)$ & NA \\
\hline Wilkinson et al, 2008 & $14 \%(63 / 441)$ & As-treated: $51 \%(25 / 49)^{3}$ \\
\hline Witteck et al, 2011 & $15 \%(29 / 193)$ & Intent-to-treat: 52\% (13/25) \\
\hline
\end{tabular}

1. Calculated according to the number of treatment outcomes $(\mathrm{N}=99)$ rather than the number of patients who initiated therapy $(\mathrm{N}=81)$

2. The study by Moussalli et al includes separate study populations for an observational phase ( $\mathrm{N}=113$ ) and an intervention phase ( $\mathrm{N}=224)$, and those study populations are represented by two separate records in this table.

3. Calculated according to the number of treatment outcomes $(\mathrm{N}=49)$ rather than the number of patients who completed therapy $(\mathrm{N}=58)$

Table 4 Treatment uptake as defined by percentage of eligible study participants who received treatment, with eligibility for treatment determined by hepatitis C RNA-positive status and other criteria

\begin{tabular}{|c|c|c|}
\hline Author, year & $\%$ treated (\# treated/\# of treatment candidates) & SVR (\%) (\# with sustained viral response/\# treated) \\
\hline Defossez et al, 2008 & $24 \%(13 / 55)^{1}$ & NA \\
\hline Grando-Lemaire et al, 2002 & $58 \%(27 / 47)$ & $\begin{array}{l}\text { Intent-to-treat: 19\% (5/27) } \\
\text { As-treated: } 33 \%(5 / 15)\end{array}$ \\
\hline Jack et al, 2009 & $70 \%(30 / 43)$ & $\begin{array}{c}\text { Intent-to-treat: } 62 \%(13 / 21) \\
\text { As-treated: } 77 \%(13 / 17)\end{array}$ \\
\hline Jowett et al, 2000 & $50 \%(50 / 100)$ & Intent-to-treat: $36 \%(18 / 50)$ \\
\hline Kristensen et al, 2009 & $33 \%(6 / 9)$ & NA \\
\hline Lindenburg et al, 2011 & $76 \%(58 / 76)$ & $\begin{array}{l}\text { Intent-to-treat: } 65 \%(37 / 57) \\
\text { As-treated: } 77 \%(37 / 48)\end{array}$ \\
\hline
\end{tabular}

1. Study population represents study cohorts from a cross-sectional survey carried out at three time points: $1997(\mathrm{~N}=26), 2000(\mathrm{~N}=11)$ and 2003 ( $\mathrm{N}=18)$. 
Data on sustained viral response (SVR) were available for 15 of the 25 studies [16-18,21,22,24,25,31-35,37,38,40] included in the review, with some studies reporting intentto-treat outcomes, some studies reporting as-treated outcomes, and some studies reporting both (Tables 2, 3, 4). For 14 studies with intent-to-treat data, the proportion of treated study participants attaining a sustained viral response ranged from 19\% to $88 \%$ (median, 55\%). For nine studies with as-treated data, SVR levels ranged from $33 \%$ to $100 \%$ (median, $80 \%$ ).

\section{Treatment uptake levels for key drug-using populations} For 11 studies [20,22-25,27,28,30,33,36,37] included in the review, treatment uptake levels could be calculated specifically for current and former PWID (Table 5). (Other studies had study populations that included non-injecting drug users.) In these studies, the HCV antibody-positive treatment uptake level ranged from $20 \%$ to $64 \%$ (three studies, median $39 \%$ ). The $\mathrm{HCV}$ RNA-positive treatment uptake level ranged from $0 \%$ to $57 \%$ (nine studies, median $32 \%$ ). For two studies reporting treatment uptake in terms of RNA-positive status plus additional criteria, treatment uptake levels were $50 \%$ and $71 \%$.

Five of the PWID-specific studies reported intent-totreat SVR levels [22,24,25,33,37]; these ranged from $22 \%$ to $56 \%$ (median, 43\%) (Table 5). Two reported as-treated SVR levels [33,37]; these were $85 \%$ and $100 \%$.
For four studies included in the review [18,22,26,35], treatment uptake levels could be calculated specifically for people receiving opioid substitution therapy (OST) (Table 6). (Some other study populations included both people receiving OST and people not receiving OST.) In these studies, the HCV antibody-positive treatment uptake level ranged from $3 \%$ to $31 \%$ (three studies, median 9\%). The HCV RNA-positive treatment uptake level ranged from $10 \%$ to $47 \%$ (three studies, median $15 \%$ ). For one study reporting treatment uptake in terms of RNA-positive status plus additional criteria, the treatment uptake level was $72 \%$.

Three of the OST-specific studies reported intent-totreat SVR levels $[18,22,35]$; these ranged from $36 \%$ to $69 \%$ (median, 52\%) (Table 6). One reported an as-treated SVR level [35]; this was $86 \%$.

Among the 25 studies, only one provided treatment uptake data specifically for current drug users. Cournot et al [22] reported on a study population of current and former PWID, including people receiving OST. Disaggregated data for current drug users indicated an $\mathrm{HCV}$ antibody-positive treatment uptake level of 39\% (16/41). The HCV RNA-positive treatment uptake level for the same study subset was 50\% (16/32). Among current drug users who were HCV RNA-positive and met additional criteria, treatment uptake was 55\% (16/29). The intent-to-treat SVR for current drug users in the study by Cournot et al was 16\% (data not shown).

Table 5 Treatment uptake in study cohorts of people who inject drugs (current and former)

\begin{tabular}{|c|c|c|}
\hline Author, year & $\%$ treated (\# treated/\# of treatment candidates & SVR (\%) (\# with sustained viral response/\# treated) \\
\hline Broers et al, 2005 & $61 \%$ of RNA+ (11/18) & $\begin{array}{l}\text { Intent-to-treat: } 56 \%(6 / 11) \\
\text { As-treated: } 100 \%(3 / 3)\end{array}$ \\
\hline \multirow[t]{3}{*}{ Cournot et al, 2004} & $39 \%$ of antibody+ (58/150) & Intent-to-treat: $22 \%(15 / 68)^{1}$ \\
\hline & $57 \%$ of RNA+ (58/102) & \\
\hline & $71 \%$ of other $(58 / 82)$ & \\
\hline Crespo et al, 2001 & $64 \%$ of antibody+ (268/416) & NA \\
\hline Gazdag et al, 2010 & $47 \%$ of RNA+ $(39 / 83)$ & NA \\
\hline Guadagnino et al, 2007 & $31 \%$ of RNA+ (53/169) & $\begin{array}{l}\text { Intent-to-treat: } 55 \%(29 / 53) \\
\text { As-treated: } 85 \%(29 / 34)\end{array}$ \\
\hline Hernandez et al, 2009 & $0 \%$ of $R N A+(0 / 4)$ & NA \\
\hline \multirow[t]{3}{*}{ Jowett et al, 2000} & $20 \%$ of antibody+ (50/253) & Intent-to-treat: 36\% (18/50) \\
\hline & $29 \%$ of RNA+ (50/172) & \\
\hline & $50 \%$ of other $(50 / 100)$ & \\
\hline Kieran et al, 2011 & $21 \%$ of RNA+ $(67 / 327)$ & Intent-to-treat: 43\% (29/67) \\
\hline Perez-Alvarez et al, 2012 & $56 \%$ of RNA+ (15/27) & NA \\
\hline Reiberger et al, 2011 & $32 \%$ of RNA+ $(201 / 637)$ & NA \\
\hline van der Veen, 2009 & $48 \%$ of $\mathrm{RNA}+(35 / 73)$ & NA \\
\hline
\end{tabular}

Antibody+ = study participants who are hepatitis $C$ antibody-positive

RNA+ = study participants who are hepatitis C RNA-positive

Other = study participants who are hepatitis C RNA-positive and meet additional treatment criteria

1. Calculated according to the number of treatment outcomes $(\mathrm{N}=68)$ rather than the number of patients who initiated therapy $(\mathrm{N}=58)$ 
Table 6 Treatment uptake in study cohorts receiving opioid substitution therapy

\begin{tabular}{|c|c|c|}
\hline Author, year & $\%$ treated (\# treated/\# of treatment candidates & SVR (\%) (\# with sustained viral response/\# treated) \\
\hline \multirow[t]{3}{*}{ Cournot et al, 2004} & $31 \%$ of antibody+ (23/75) & Intent-to-treat: $36 \%(11 / 31)^{1}$ \\
\hline & $47 \%$ of RNA+ (23/49) & \\
\hline & $72 \%$ of other $(23 / 32)$ & \\
\hline \multirow[t]{2}{*}{ Cullen et al, 2007} & $3 \%$ of antibody+ (3/104) & NA \\
\hline & $10 \%$ of RNA+ (3/29) & \\
\hline Schulte et al, $2010^{2}$ & $9 \%$ of antibody+ (26/301) & $\begin{array}{l}\text { Intent-to-treat: 69\% (18/26) } \\
\text { As-treated: 86\% (18/21) }\end{array}$ \\
\hline Witteck et al, $2011^{2}$ & $15 \%$ of RNA+ (29/193) & Intent-to-treat: 52\% (13/25) \\
\hline
\end{tabular}

Antibody+ = study participants who are hepatitis $C$ antibody-positive

RNA+ = study participants who are hepatitis C RNA-positive

Other = study participants who are hepatitis C RNA-positive and meet additional treatment criteria

1. Calculated according to the number of treatment outcomes $(\mathrm{N}=31)$ rather than the number of patients who initiated therapy $(\mathrm{N}=23)$

2. Study cohort received heroin maintenance therapy

\section{Age and sex of treatment initiators}

The mean age of HCV treatment initiators was available for eight studies; it ranged from 29 to 48 (mean, 34). In the nine studies that disaggregated the sex of treatment initiators, the percentage of female treatment initiators ranged from $9 \%$ to $85 \%$ (mean, 26\%) (data not shown).

\section{Discussion}

This systematic review found that hepatitis $C$ treatment uptake is relatively low among drug users in several countries in the WHO European Region, and also that considerable knowledge gaps exist regarding treatment uptake levels in drug users generally and people who inject drugs specifically. There was large variability in treatment uptake levels, with six studies reporting treatment uptake levels below 20\% in HCV RNA-positive drug-using study populations, while four reported treatment uptake levels of $50 \%$ or higher. However, the median treatment uptake level was alarmingly low, at $30 \%$.

The apparent failure of many European health systems to engage a key population that needs HCV treatment is even more striking in light of the health care resources that appear to be available. For example, the governments of France, Ireland, Spain and the United Kingdom all have reported that the HCV drugs interferon alpha, pegylated interferon, ribavirin, boceprevir and telaprevir are either government-subsidised or are on the national essential medicines lists in those countries [41]. Yet 14 studies from those countries are among the studies demonstrating low treatment uptake among drug users. This may partially reflect recent findings from a survey of civil society organisations, which reports low capacity and extremely limited resources among non-governmental organisations addressing hepatitis [42].

The majority of studies identified by our review included both people who inject drugs and non-injecting drug users in their study populations without providing disaggregated data for these two subgroups. Interestingly, the 11 articles with data specifically for people who inject drugs showed a median treatment uptake level of $32 \%$ among HCV RNApositive PWID - comparable to the median treatment uptake level for the full set of studies. Nonetheless, the fact remains that policy-makers, programme managers and researchers currently possess extremely limited information about the extent to which hepatitis $C$ treatment is reaching the population whose primary risk behaviour injecting drug use - is the main driver of the hepatitis $C$ epidemic in Europe.

The current situation is likely a legacy of the medical community's initial outlook on hepatitis $\mathrm{C}$ treatment for PWID, which was to not treat current or even past injectors. Although treatment adherence, efficacy and safety have been shown to be quite comparable between PWID and those with no history of drug use, several international and national treatment guidelines in the 1990s and at the beginning of the new millennium excluded PWID from being treated for hepatitis $C[8,9,43]$. In a revision of its guidelines in 2011, the European Association for the Study of the Liver (EASL) made the important decision to advise instituting antiviral therapy in PWID on stable maintenance substitution treatment after careful individual evaluation by an interdisciplinary team of hepatologists and addiction specialists. As for current drug injectors, an individualised approach after evaluation and close monitoring by an experienced multidisciplinary team were recommended [44].

EASL published a new revision of its guidelines in 2013, and this document reflects the continuing evolution of medical perspectives on the treatment of hepatitis $\mathrm{C}$ in drug users and patients on stable maintenance substitution therapy [45]. According to the guidelines, $\mathrm{HCV}$ treatment should be considered for PWID on a case-bycase basis, provided they wish to receive it and are willing and able to maintain regular follow-up visits to a multidisciplinary medical service as well as obtain a pre-treatment assessment. The assessment should take into 
account several factors that may influence adherence to therapy and the likelihood of achieving a sustained viral response, such as ongoing drug use, alcohol consumption, psychiatric disorders, housing, education, employment, and social and financial status. Accordingly, closer monitoring and more intensive multidisciplinary support are needed in certain cases.

The problem is that there appears to be a vast gulf between evidence-based best practice and the decisionmaking of physicians who encounter HCV RNA-positive drug users seeking care in their clinics. Research indicates that some physicians are reluctant to provide hepatitis $C$ treatment to people who inject drugs, especially those whose drug use is ongoing. For example, a study of private practitioners in Switzerland found that a major reason for non-treatment was intravenous drug use [46].

Even in a research context, where one might hope that treatment criteria for participant-patients are determined in keeping with the established evidence base, current illicit drug use seems to be a legitimate reason for not providing HCV treatment. For example, a 2009 article included in our review described a study that sought "to assess the feasibility and efficacy of antiviral therapy in opioid-dependent patients" by providing one of two HCV treatment regimens to patients at an Austrian addiction clinic. However, participation in the study required meeting one or both of two conditions at the time of enrolment: being in drug maintenance therapy, and abstaining from illicit drugs for at least six months [16].

Other factors commonly associated with injecting drug use may result in the patient's drug use indirectly creating barriers to HCV treatment. For example, a 2011 article included in the review describes a prospective cohort study in which Dutch drug users were referred to a multidisciplinary hepatitis $\mathrm{C}$ treatment unit. Current drug and alcohol use were not considered treatment exclusion criteria. However, in order to be eligible for treatment, drug users "were required to have stable housing and no acute or uncared for juridical or financial impediments" [40]. Another study excluded hepatitis patients coinfected with HIV [31]. While in the context of a study there may be legitimate scientific reasons for excluding certain categories of would-be study participants, in order to avoid potential confounding of the results, these examples do illustrate some of the barriers PWID face in being treated for their life-threatening condition.

Several studies have shown that treatment of PWID with pegylated interferon alpha plus ribavirin has resulted in sustained viral response levels of 54 to $56 \%[8,9,47]$ confirming that HCV-infected PWID can be successfully treated. There are some independent factors associated with lower SVR in this group of patients, such as untreated depression, poor socialization and ongoing drug use during HCV treatment $[48,49]$. On the other hand, PWID in many cases present baseline characteristics shown to be associated with sustained viral response, such as young age and mild liver disease [50]. The mean age in the studies included in this review ranged from 29 to 48, with an aggregated mean of 34 .

It has also been reported that a large obstacle to $\mathrm{HCV}$ treatment and care for PWID is related to access to care, described as a lack of treatment settings that are suitable for this vulnerable group [12]. Various models for $\mathrm{HCV}$ treatment delivery were employed in the articles included in our review. The 2013 EASL guidelines call for a multidisciplinary approach regarding the treatment of $\mathrm{HCV}$ infection in PWID including hepatologists and addiction specialists, possibly combining them with other specialists. Therapy can be delivered at community-based clinics, substance use treatment clinics or specialised clinics for the treatment of viral hepatitis. Other options exist as well, such as integrating treatment into primary, secondary or tertiary care, as well as integrating interventions such as directly observed therapy and peer treatment support [5]. The best way to reach the maximum number of infected PWID is to offer the range of various local settings and enable close ongoing collaboration of all involved health professionals [5]. It is now time to further rethink treatment and models of care for PWID.

Treatment not only has the likelihood of curing an individual's HCV infection, but as in the field of HIV/AIDS, treatment as prevention is increasingly recognised [51]. Mathematical models predict that the transmission rate is reduced when treatment uptake is increased [52-54]. Hence the apparent widespread failure to engage many PWID who have hepatitis $C$ in treatment represents not only missed opportunities to avert potential suffering and death from liver diseases on an individual level, but also missed opportunities to slow an epidemic of major public health significance.

\section{Limitations}

This literature review has several limitations which may affect the findings. The review primarily contains studies retrieved through PUBMED and EMBASE, which means that the data are subject to publication bias. Drawing on the protocol and methods from a previously published study [15] these problems have been minimised by including missed studies, including studies reported in other languages, provided by a network of drug and infectious disease experts in the European Union. Even with this additional component of the literature search, the 25 articles that met review criteria represent only 12 of the European Region's 53 Member States. Furthermore, estimates of treatment entry are higher than in that of a recent previous study [15] as there, estimates were only presented for non-intervention (i.e. observational) studies performed in non-clinical settings, whereas in this analysis 
we included all data available, noting the fact that estimates are partly based on selected populations. The data in our study are thus not directly comparable to the estimates of the previous study, which as its main finding found that overall a lower median (9.5\%) of PWID who were diagnosed with $\mathrm{HCV}$ among six observational and non-clinical studies had received treatment. Further study including meta-analysis is needed to better understand the biases and generalisability of estimates of treatment access.

Large differences in treatment uptake were observed across the studies included in this review, but since there were major variations in study design and methodology, it is possible that treatment uptake findings may reflect these differences rather than real differences in treatment uptake within and across countries. The following important potential biases may have further influenced the review findings. The included studies were largely undertaken in various types of health care settings, and the drug-using populations served in those settings may not be representative of all people who use drugs. In a number of studies, treatment delivery models were designed with the goal of attracting and retaining people who use drugs, for example by making treatment available at opioid substitution therapy clinics. In light of these considerations, it can be expected that the percentages of people initiating treatment would be higher than the percentage of drug users who are actually initiating treatment in the population at large.

A number of articles were excluded from this review because of methodological shortcomings. Some reported the number of drug users initiating $\mathrm{HCV}$ treatment but did not report the total number of drug users who were treatment candidates, making it impossible to determine the proportion of treatment initiators (referred to in this article as the treatment uptake level) [55-59]. Other articles needed to be excluded because they failed to explain how treatment candidates were defined, i.e., it was not clear if patients were considered treatment candidates on the basis of their HCV antibody status, HCV-RNA status or other criteria. Finally, although not part of the exclusion criteria, most studies do not mention whether or not patients were treatment naïve or if previous treatment regimens had been discontinued due to, for example, intolerance/side-effects or failure.

\section{Conclusions}

The availability of hepatitis $\mathrm{C}$ treatment data for drugusing populations varies greatly across the WHO European Region. To the extent that treatment uptake levels can be measured, it appears that major differences exist in the proportions of drug users who undergo hepatitis $\mathrm{C}$ treatment in different research settings. However, the overall finding of this review suggests to is that large proportions of people who use drugs, including those who inject drugs, do not enter the treatment pathway and do not receive treatment for their hepatitis C infection.

This observation, coupled with evidence showing that some physicians consider illicit drug use, HIV coinfection and/or related social issues to be counter-indications for hepatitis $C$ treatment, leads us to suggest that a promising strategy for improving the situation is working to increase knowledge and reduce misconceptions among physicians, who play a pivotal role in encouraging or discouraging the initiation of treatment in drug users. There is furthermore great potential to build on integrated health care models, both governmental and nongovernmental, that have demonstrated some success in providing drug users with the medical and social support services that they need in order to optimise their chances of benefitting from hepatitis $C$ treatment. All such efforts must be situated within stronger national efforts to develop HCV treatment policies, strengthen service organisations and ultimately scale up HCV treatment for PWID. In the research realm, future studies should ensure the inclusion of clear criteria to determine if treatment for $\mathrm{HCV}$ is needed and should report the indications for starting treatment. This, at a minimum, would include HCV-RNA status, which a number of the excluded articles for this review failed to report.

\section{Competing interests}

The authors declare that they have no competing interests.

\section{Declarations}

This article has been published as part of BMC Infectious Diseases Volume 14 Supplement 6, 2014: Viral Hepatitis in Europe. The full contents of the supplement are available online at http://www.biomedcentral.com/ bmcinfectdis/supplements/14/S6. The publication charges for this supplement were funded by AbbVie as an unrestricted grant to Rigshospitalet, the University of Copenhagen. AbbVie further funded the printing of the supplement with additional financial support from the Drug Prevention and Information Programme (DPIP) of the European Union.

\section{Authors' details}

${ }^{1} \mathrm{CHIP}$, Centre for Health and Infectious Disease Research and WHO

Collaborating Centre on HIV and Viral Hepatitis, Rigshospitalet, University of Copenhagen, Copenhagen, Denmark. ${ }^{2}$ Clinic for Infectious Diseases and Febrile Illnesses, University Medical Centre Ljubljana, Ljubljana, Slovenia. ${ }^{3}$ European Monitoring Centre for Drugs and Drug Addiction (EMCDDA), Lisbon, Portugal.

Published: 19 September 2014

\section{References}

1. Mohd HK, Groeger J, Flaxman AD, Wiersma ST: Global epidemiology of hepatitis $C$ virus infection: new estimates of age-specific antibody to HCV seroprevalence. Hepatology 2013, 57:1333-1342.

2. World Health Organization: Guidelines for the screening, care and treatment of persons with hepatitis C infection. Geneva, Switzerland; 2014.

3. Perz JF, Armstrong GL, Farrington LA, Hutin YJ, Bell BP: The contributions of hepatitis $B$ virus and hepatitis $C$ virus infections to cirrhosis and primary liver cancer worldwide. J Hepatol 2006, 45:529-538.

4. Lozano R, Naghavi M, Foreman K, Lim S, Shibuya K, Aboyans V, et al: Global and regional mortality from 235 causes of death for 20 age groups in 1990 and 2010: a systematic analysis for the Global Burden of Disease Study 2010. Lancet 2012, 380:2095-2128. 
5. Hope VD, Eramova I, Capurro D, Donoghoe MC: Prevalence and estimation of hepatitis B and C infections in the WHO European Region: a review of data focusing on the countries outside the European Union and the European Free Trade Association. Epidemiol Infect 2014, 142:270-286.

6. Hahne SJ, Veldhuijzen IK, Wiessing L, Lim TA, Salminen M, Laar M: Infection with hepatitis $B$ and $C$ virus in Europe: a systematic review of prevalence and cost-effectiveness of screening. BMC Infect Dis 2013, 13:181.

7. EMCDDA: European Drug Report 2013: Trends and development. Lisbon, Portugal, EMCDDA; 2013

8. Aspinall EJ, Corson S, Doyle JS, Grebely J, Hutchinson SJ, Dore GJ, et al: Treatment of hepatitis $C$ virus infection among people who are actively injecting drugs: a systematic review and meta-analysis. Clin Infect Dis 2013, 57(Suppl 2):S80-S89.

9. Hellard M, Sacks-Davis R, Gold J: Hepatitis C treatment for injection drug users: a review of the available evidence. Clin Infect Dis 2009, 49:561-573.

10. Martin NK, Vickerman P, Miners A, Foster GR, Hutchinson SJ, Goldberg DJ, et al: Cost-effectiveness of hepatitis $C$ virus antiviral treatment for injection drug user populations. Hepatology 2012, 55:49-57.

11. Bruggmann P: Accessing Hepatitis $C$ patients who are difficult to reach: it is time to overcome barriers. J Viral Hepat 2012, 19:829-835.

12. Bruggmann $\mathrm{P}$, Litwin $\mathrm{AH}$ : Models of care for the management of hepatitis $C$ virus among people who inject drugs: one size does not fit all. Clin Infect Dis 2013, 57(Suppl 2):S56-S61.

13. Treloar C, Rance J, Backmund M: Understanding barriers to hepatitis C virus care and stigmatization from a social perspective. Clin Infect Dis 2013, 57(Suppl 2):S51-S55.

14. Liberati A, Altman DG, Tetzlaff J, Mulrow C, Gotzsche PC, loannidis JP, et al: The PRISMA statement for reporting systematic reviews and metaanalyses of studies that evaluate health care interventions: explanation and elaboration. PLoS Med 2009, 6:e1000100.

15. Wiessing L, Ferri M, Grady B, Kantzanou M, Sperle I, Cullen KJ, et al: Hepatitis C Virus Infection Epidemiology among People Who Inject Drugs in Europe: A Systematic Review of Data for Scaling Up Treatment and Prevention. PLoS One 2014, 9:e103345.

16. Ebner N, Wanner C, Winklbaur B, Matzenauer C, Jachmann CA, Thau K, et al: Retention rate and side effects in a prospective trial on hepatitis $C$ treatment with pegylated interferon alpha-2a and ribavirin in opioiddependent patients. Addict Biol 2009, 14:227-237.

17. Moussalli J, Delaquaize H, Boubilley D, Lhomme JP, Merleau PJ, Sabot D, et al: Factors to improve the management of hepatitis $C$ in drug users: an observational study in an addiction centre. Gastroenterol Res Pract 2010

18. Witteck A, Schmid P, Hensel-Koch K, Thurnheer MC, Bruggmann P, Vernazza P: Management of hepatitis $C$ virus (HCV) infection in drug substitution programs. Swiss Med Wkly 2011, 141:w13193.

19. Defossez G, Verneau A, Ingrand I, Silvain C, Ingrand P, Beauchant M: Evaluation of the French national plan to promote screening and early management of viral hepatitis C, between 1997 and 2003: a comparative cross-sectional study in Poitou-Charentes region. Eur Gastroenterol Hepatol 2008, 20:367-372.

20. Van Veen M: Briefrapport Infectieziektebestrijding in de verslavingszorg in Nederland. 2009.

21. Wilkinson M, Crawford V, Tippet A, Jolly F, Turton J, Sims E, et al: Community-based treatment for chronic hepatitis $C$ in drug users: High rates of compliance with therapy despite ongoing drug use. Alimentary Pharmacology and Therapeutics 2009, 29.

22. Cournot M, Glibert A, Castel F, Druart F, Imani K, Lauwers-Cances V, et al: Management of hepatitis $C$ in active drugs users: experience of an addiction care hepatology unit. Gastroenterol Clin Biol 2004, 28:533-539.

23. Gazdag G, Horvath G, Szabo O, Ungvari GS: Barriers to antiviral treatment in hepatitis $C$ infected intravenous drug users. Neuropsychopharmacol Hung 2010, 12:459-462

24. Jowett SL, Agarwal K, Smith BC, Craig W, Hewett M, Bassendine DR, et al: Managing chronic hepatitis $C$ acquired through intravenous drug use. QJM 2001, 94:153-158.

25. Kieran J, Dillon A, Farrell G, Jackson A, Norris S, Mulcahy F, et al: High uptake of hepatitis $C$ virus treatment in HIV/hepatitis $C$ virus co-infected patients attending an integrated HIV/hepatitis C virus clinic. Int J STD AIDS 2011, 22:571-576.
26. Cullen W, Stanley J, Langton D, Kelly Y, Bury G: Management of hepatitis C among drug users attending general practice in Ireland: baseline data from the Dublin area hepatitis C in general practice initiative. Eur J Gen Pract 2007, 13:5-12.

27. Hernandez FM, Rodriguez San Roman JL, Martin Suarez JM, Pena-Lopez MJ: [Acute hepatitis due to hepatitis $C$ virus infection in the adult population]. Gastroenterol Hepatol 2009, 32:677-680.

28. Perez-Alvarez R, Garcia-Samaniego J, Sola R, Perez-Lopez R, Barcena R, Planas $R$, et al: Acute hepatitis $C$ in Spain: a retrospective study of 131 cases. Rev Esp Enferm Dig 2012, 104:21-28.

29. Perut V, Labalette C, Sogni P, Ferrand I, Salmon-Ceron D, Vidal-Trecan G: Access to care of patients with chronic hepatitis $C$ virus infection in a university hospital: Is opioid dependence a limiting condition? Drug Alcohol Depend 2009, 104:78-83.

30. Reiberger T, Obermeier M, Payer BA, Baumgarten A, Weitner L, Moll A, et al: Considerable under-treatment of chronic HCV infection in HIV patients despite acceptable sustained virological response rates in a real-life setting. Antivir Ther 2011, 16:815-824.

31. Backmund M, Meyer K, Von ZM, Eichenlaub D: Treatment of hepatitis C infection in injection drug users. Hepatology 2001, 34:188-193.

32. Grando-Lemaire V, Goisset P, Sorge F, Trinchet JC, Castera L, Roulot D, et al: [Hepatitis $C$ virus screening in drug users in an addiction out-patient unit]. Gastroenterol Clin Biol 2002, 26:1091-1096.

33. Guadagnino V, Trotta MP, Montesano F, Babudieri S, Caroleo B, Armignacco $O$, et al: Effectiveness of a multi-disciplinary standardized management model in the treatment of chronic hepatitis $C$ in drug addicts engaged in detoxification programmes. Addiction 2007, 102:423-431

34. McCormick PA, Keavney M, O'Toole S, Moloney J: Methadone and HCV treatment. Ir Med J 2008, 101:316-317.

35. Schulte B, Schutt S, Brack J, Isernhagen K, Deibler P, Dilg C, et al: Successful treatment of chronic hepatitis $C$ virus infection in severely opioiddependent patients under heroin maintenance. Drug Alcohol Depend 2010, 109:248-251.

36. Crespo J, Garcia F, Castro B, Pons F: Chronic hepatitis (HCV) among intravenous drug users (IDU); reasons for not initiating the antiviral treatment. [Spanish]. Adicciones 2001, 13.

37. Broers B, Helbling B, Francois A, Schmid P, Chuard C, Hadengue A, et al: Barriers to interferon-alpha therapy are higher in intravenous drug users than in other patients with acute hepatitis C. J Hepatol 2005, 42:323-328.

38. Jack K, Willott S, Manners J, Varnam MA, Thomson BJ: Clinical trial: a primary-care-based model for the delivery of anti-viral treatment to injecting drug users infected with hepatitis C. Aliment Pharmacol Ther 2009, 29:38-45

39. Kristensen O, Sundoy A, Skeie K, Vederhus JK, Oye I, Opsal A, et al: [Shortterm treatment of Hepatitis $C$ in heroin-dependent patients]. Tidsskr Nor Laegeforen 2009, 129:1639-1642.

40. Lindenburg CE, Lambers FA, Urbanus AT, Schinkel J, Jansen PL, Krol A, et al: Hepatitis $C$ testing and treatment among active drug users in Amsterdam: results from the DUTCH-C project. Eur J Gastroenterol Hepatol 2011, 23:23-31

41. World Health Organization: Global policy report on the prevention and control of viral hepatitis. 2013

42. World Hepatitis Alliance: Global Community Hepatitis Policy Report. 2014.

43. EASL International Consensus Conference on Hepatitis C. Paris, 26-28, February 1999, Consensus Statement. European Association for the Study of the Liver. J Hepatol 1999, 30:956-961.

44. EASL Clinical Practice Guidelines: management of hepatitis $C$ virus infection. J Hepatol 2011, 55:245-264.

45. EASL Clinical Practice Guidelines: management of hepatitis $C$ virus infection. J Hepatol 2014, 60:392-420.

46. Overbeck K, Bruggmann P, Helbling B: Chronic Hepatitis C virus infection in Swiss primary care practices: low case loads-high barriers to treatment? Eur J Gen Pract 2011, 17:103-108.

47. John-Baptiste A, Krahn M, Heathcote J, Laporte A, Tomlinson G: The natural history of hepatitis $C$ infection acquired through injection drug use: meta-analysis and meta-regression. J Hepatol 2010, 53:245-251.

48. Dore GJ, Hellard M, Matthews GV, Grebely J, Haber PS, Petoumenos K, et al: Effective treatment of injecting drug users with recently acquired hepatitis C virus infection. Gastroenterology 2010, 138:123-135. 
49. Alvarez-Uria G, Day JN, Nasir AJ, Russell SK, Vilar FJ: Factors associated with treatment failure of patients with psychiatric diseases and injecting drug users in the treatment of genotype 2 or 3 hepatitis C chronic infection. Liver Int 2009, 29:1051-1055.

50. Melin P, Chousterman M, Fontanges T, Ouzan D, Rotily M, Lang JP, et al: Effectiveness of chronic hepatitis $C$ treatment in drug users in routine clinical practice: results of a prospective cohort study. Eur I Gastroenterol Hepatol 2010, 22:1050-1057.

51. World Health Organization: Programmatic Update. Antiretroviral Treatment as Prevention (TASP) of HIV and TB. Geneva, World Health Organization; 2012.

52. Zeiler I, Langlands T, Murray JM, Ritter A: Optimal targeting of Hepatitis C virus treatment among injecting drug users to those not enrolled in methadone maintenance programs. Drug Alcohol Depend 2010, 110:228-233

53. Vickerman $\mathrm{P}$, Martin N, Hickman M: Can Hepatitis C virus treatment be used as a prevention strategy? Additional model projections for Australia and elsewhere. Drug Alcohol Depend 2011, 113:83-85.

54. Martin NK, Vickerman P, Foster GR, Hutchinson SJ, Goldberg DJ, Hickman M Can antiviral therapy for hepatitis $\mathrm{C}$ reduce the prevalence of HCV among injecting drug user populations? A modeling analysis of its prevention utility. J Hepatol 2011, 54:1137-1144.

55. Robaeys G, Van VH, Mathei C, Van RM, Bruckers L, Buntinx F: Similar compliance and effect of treatment in chronic hepatitis $C$ resulting from intravenous drug use in comparison with other infection causes. Eur $J$ Gastroenterol Hepatol 2006, 18:159-166.

56. Lowry DJ, Ryan JD, Ullah N, Kelleher TB, Crowe J: Hepatitis C management: the challenge of dropout associated with male sex and injection drug use. Eur I Gastroenterol Hepatol 2011, 23:32-40.

57. Medrano J, Resino S, Vispo E, Madejon A, Labarga P, Tuma P, et al: Hepatitis $C$ virus $(\mathrm{HCV})$ treatment uptake and changes in the prevalence of HCV genotypes in HIV/HCV-coinfected patients. J Viral Hepat 2011, 18:325-330.

58. Dalgard O, Bjoro K, Hellum K, Myrvang B, Skaug K, Gutigard B, et al: Treatment of chronic hepatitis $C$ in injecting drug users: 5 years' followup. Eur Addict Res 2002, 8:45-49.

59. Fried R, Monnat M, Seidenberg A, Oppliger R, Schmid P, Herold M, et al: Swiss multicenter study evaluating the efficacy, feasibility and safety of peginterferon-alfa-2a and ribavirin in patients with chronic hepatitis $C$ in official opiate substitution programs. Digestion 78.

doi:10.1186/1471-2334-14-S6-S16

Cite this article as: Lazarus et al: A systematic review of Hepatitis C virus treatment uptake among people who inject drugs in the European Region. BMC Infectious Diseases 2014 14(Suppl 6):S16.

\section{Submit your next manuscript to BioMed Central and take full advantage of:}

- Convenient online submission

- Thorough peer review

- No space constraints or color figure charges

- Immediate publication on acceptance

- Inclusion in PubMed, CAS, Scopus and Google Scholar

- Research which is freely available for redistribution

Submit your manuscript at www.biomedcentral.com/submit
Biomed Central 